\title{
Behavioral impairment and increased predation mortality in cutthroat trout exposed to carbaryl
}

\author{
Jana S. Labenia ${ }^{1}$, David H. Baldwin ${ }^{1}$, Barbara L. French ${ }^{1}$, Jay W. Davis ${ }^{2}$, \\ Nathaniel L. Scholz ${ }^{1, *}$ \\ ${ }^{1}$ NOAA Fisheries, Northwest Fisheries Science Center, 2725 Montlake Boulevard E, Seattle, Washington 98112, USA \\ ${ }^{2}$ US Fish and Wildlife Service, Western Washington Fish and Wildlife Office, 510 Desmond Drive SE, Lacey, \\ Washington 98503, USA
}

\begin{abstract}
Willapa Bay is a coastal estuary in Washington State that provides seasonal rearing habitat for anadromous cutthroat trout Oncorhynchus clarki clarki. Cutthroat trout forage throughout the estuary in the summer months when carbaryl, a carbamate insecticide, is applied to oyster beds via aerial spraying and other application methods to control burrowing shrimp populations. The insecticide interferes with normal nervous system function in trout via the inhibition of acetylcholinesterase, an enzyme that regulates neurotransmitter-mediated signaling at synapses. In the present study, we show that the olfactory system of trout is unresponsive to carbaryl, and that trout do not avoid seawater containing the pesticide at environmentally representative concentrations. Short-term (6 h) carbaryl exposures significantly reduced acetylcholinesterase activity in both brain and muscle in a dose-dependent manner. Enzyme activity gradually recovered over $42 \mathrm{~h}$ following carbaryl exposure $\left(6 \mathrm{~h}\right.$ at $\left.500 \mathrm{\mu g} \mathrm{l}^{-1}\right)$. In tests of swimming performance, trout were unable to orient to directional flow and swim effectively at exposure concentrations $\geq 750 \mu \mathrm{g} \mathrm{l} \mathrm{l}^{-1}$. Finally, we determined rates of predation by lingcod Ophiodon elongatus on carbaryl-exposed and unexposed trout. Exposed animals were consumed by predators at significantly higher rates at concentrations $\geq 500 \mu \mathrm{g} \mathrm{l}^{-1}$. We conclude that cutthroat trout are unlikely to avoid carbaryl-contaminated seawater, and that estuarine applications are likely to cause neurobehavioral impairments in trout that may increase individual mortality due to predation.
\end{abstract}

KEY WORDS: Pesticide · Behavioral avoidance · Carbamate $\cdot$ Acetylcholinesterase $\cdot$ Olfaction $\cdot$ Predation $\cdot$ Trout $\cdot$ Estuary

Resale or republication not permitted without written consent of the publisher



Carbaryl is sprayed on tidelands in the Pacific Northwest of the USA to control burrowing shrimp on oyster beds. Cutthroat trout that use these estuaries as foraging habitat are unable to detect or avoid carbaryl in seawater, and short-term exposure reduces their swimming performance and increases predation mortality.

Photos: Si Simenstad, University of Washington (estuary); Brad E. Johns, US Fish and Wildlife Service (helicopter)

\section{INTRODUCTION}

The direct and large-scale application of pesticides to intertidal habitats is generally rare in the USA. A notable exception is the use of the insecticide carbaryl (1-napthyl $n$-methyl carbamate) to control populations of burrowing mud shrimp Upogebia pugettensis and ghost shrimp Neotrypaea californiensis in estuarine littoral flats in southwestern Washington State. Bioturbating shrimp are a threat to the commercial oyster industry in Washington, and carbaryl has been used since 1963 to remove shrimp from oyster beds in Willapa 


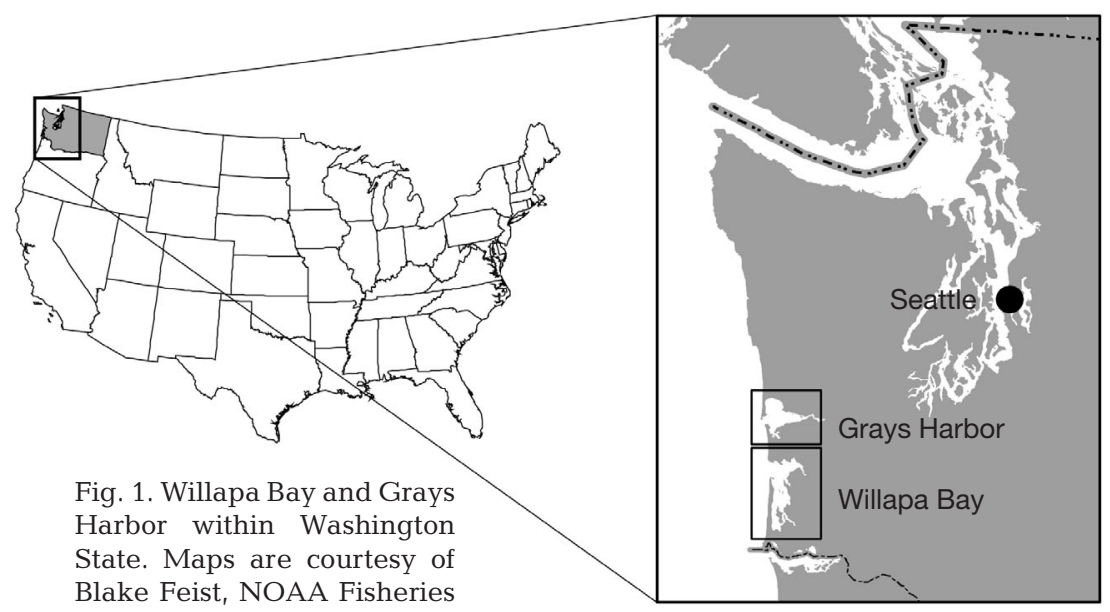

commercially important Dungeness crabs Cancer magister, are particularly sensitive to the toxic effects of carbaryl. Also killed are small fish - such as saddleback gunnels Pholis ornata, bay gobies Lepidogobius lepidus, three-spine sticklebacks Gasterosteus aculeatus, English sole Parophrys vetulus, sand sole Psettichthys melanostictus, and staghorn sculpins Leptocottus armatus-particularly those that are entrained in shallow pools at low tide. Previous field investigations have shown that carbaryl is not acutely lethal to crabs caged in off-site, subtidal channels (reviewed by Feldman et al. 2000). Because fish are generally less sensitive to carbaryl than crusta-

Bay and, to a lesser extent, in Grays Harbor (Fig. 1). The seasonal treatment of oyster beds with carbaryl continues to be controversial, due in part to concerns about potential impacts on non-target species (reviewed by Feldman et al. 2000).

Carbaryl is applied to tidelands at low spring tides in July or August of each year. A helicopter is used to spray the chemical over large tracts of exposed mudflat, and smaller areas are treated using a backpack sprayer. The rates of carbaryl application and the number of hectares (ha) treated have varied over the decades. Currently, ca. 324 ha are sprayed with carbaryl at a rate of $9 \mathrm{~kg}$ carbaryl ha ${ }^{-1}$ (Feldman et al. 2000). The incoming tide mobilizes carbaryl into the estuarine water column and transports the pesticide off-site. The concentration of dissolved carbaryl in surface waters generally decreases with distance from treated oyster beds, although the extent of this dilution can be influenced in unpredictable ways by tidal currents, turbulence, and the bathymetry of the estuary. Surface water monitoring has shown that carbaryl can reach concentrations that range from 4000 to $12000 \mathrm{\mu g} \mathrm{l}^{-1}$ within $100 \mathrm{~m}$ of treated mudflats (reviewed by Feldman et al. 2000). These levels fall to lower concentrations $\left(<1000 \mu \mathrm{g} \mathrm{l}^{-1}\right)$ at distances of $200 \mathrm{~m}$ or more. Water column concentrations are likely to remain at these high levels for only a short period of time, i.e. minutes to hours, depending on site-specific patterns of mixing and dilution.

The short- and long-term impacts of carbaryl spraying on marine invertebrate populations have been the subject of considerable research (reviewed by Feldman et al. 2000, see also Dumbauld et al. 2001). On the day of application, the acute toxicity of carbaryl to a variety of small marine fish, as well as infaunal and epibenthic invertebrates, has been extensively documented in the estuary (e.g. Armstrong \& Millemann 1974, Dumbauld et al. 2001). Crustaceans, including ceans, off-site fish kills are thought to be unlikely. However, the potential for carbaryl to have sublethal effects on fish in the vicinity of treated oyster beds has not been widely investigated.

Willapa Bay and Grays Harbor provide foraging habitat for several species of anadromous (oceangoing) salmonids that belong to the genus Oncorhynchus. Among these are cutthroat trout Oncorhynchus clarki clarki that migrate from freshwater into Washington's coastal estuaries in the summer months to forage (Simenstad et al. 1982). Coastal cutthroat trout in southwestern Washington belong to the Southwestern Washington/Columbia River distinct population segment. This population has declined in recent decades (Johnson et al. 1999), and the US Fish and Wildlife Service currently recognizes the Southwestern Washington/Columbia River distinct population segment as a species of concern (i.e. depressed, but not currently listed as threatened under the US Endangered Species Act). Coastal cutthroat trout (also known as sea-run cutthroat trout) are iteroparous, and their marine migration patterns are variable and complex relative to other salmonids (Quinn \& Myers 2004). In Washington, they typically enter protected coastal waters, beginning in the late spring. Trout spend the summer months in the shallow estuarine environment before returning to freshwater streams in the fall (Quinn \& Myers 2004). While in the estuary, trout forage opportunistically on small fish and marine arthropods along gravel beaches, around oyster beds, and in patches of eelgrass (Trotter 1989). Because of their proximity to treated oyster beds, sea-run cutthroat trout are likely to be exposed to dissolved-phase carbaryl after a spray event.

Carbaryl is a carbamate insecticide and a member of a large class of pesticides that block neurotransmission in arthropods (including crustaceans) as well as fish (Carlson et al. 1998). This is accomplished via the 
inhibition of the enzyme acetylcholinesterase (AChE). The primary function of AChE is to hydrolyze acetylcholine, a common neurotransmitter located at synapses throughout the central and peripheral nervous system of fish and other animals. Since acetylcholinemediated (or cholinergic) signaling is an integral component of neuronal transmission throughout many areas of the vertebrate nervous system (Taylor \& Brown 1999), a distributed loss of cholinergic function could potentially result in diverse forms of neurological and behavioral dysfunction. Anticholinesterase insecticides are known to be neurotoxic to salmonids (Waring \& Moore 1997, Jarrard et al. 2004, Scholz et al. 2006). For example, AChE inhibition is closely associated with reduced swimming and feeding behaviors in juvenile coho salmon Oncorhynchus kisutch (Sandahl et al. 2005). Moreover, carbaryl exposure significantly increases the vulnerability of rainbow trout $O$. mykiss to predation by largemouth bass Micropterus salmoides at exposure concentrations as low as $10 \mu \mathrm{g} \mathrm{l}^{-1}$ (Little et al. 1990).

Although carbaryl applications in Washington's coastal estuaries have the potential to impair the physiology and behavior of sea-run cutthroat trout, this has not been specifically investigated. Of key concern are behavioral effects that might render exposed fish more vulnerable to predators that hunt in the vicinity of oyster beds following carbaryl applications (WDOE 1999). Alternatively, the neurobehavioral effects of carbaryl might be mitigated to some degree if trout are able to detect and avoid carbaryl-contaminated seawater in the estuary. To explore these possibilities, we used neurophysiological recordings (the electro-olfactogram, EOG; Baldwin \& Scholz 2005) to monitor the responsiveness of the trout olfactory system to carbaryl and 2-way behavioral choice tests to assess the avoidance of trout to carbaryl-contaminated seawater. Moreover, we determined the effects of environmentally representative carbaryl exposures ( 0 to $1000 \mu \mathrm{g} \mathrm{l}^{-1}$ ) on AChE enzymatic activity in trout brain and muscle, and monitored the time course for the recovery of $\mathrm{AChE}$ activity following a short-term exposure $\left(6 \mathrm{~h}\right.$ at $\left.500 \mathrm{\mu g} \mathrm{l}^{-1}\right)$. Finally, we evaluated the effects of carbaryl on the swimming performance of trout and the ability of exposed animals to avoid predation by lingcod Ophiodon elongates, a model marine predator.

\section{MATERIALS AND METHODS}

Fishes. Cutthroat trout Oncorhynchus clarki clarki were obtained from the Washington State Department of Fish and Wildlife's Eells Springs Hatchery in Shel-

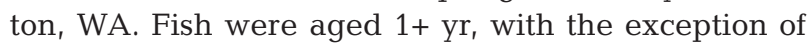
the $0+$ yr cohort used in predation trials (see 'Predator avoidance' section below). Fish were transported from the hatchery to the Northwest Fisheries Science Center's (NWFSC) marine research facility (Mukilteo, WA) and gradually acclimated to seawater over 1 to $2 \mathrm{wk}$. Fish were maintained in ca. $1.2 \mathrm{~m}$ diameter (ca. $700 \mathrm{l}$ ) tanks with filtered, UV-sterilized seawater throughout the study and were fed Lifestages Diets for Fish (Bio-Oregon) at $1.5 \%$ of body weight. Prior to surgical procedures, fish were anaesthetized with tricaine methane sulfonate (5 $\mathrm{g} \mathrm{l}^{-1} \mathrm{MS}-222 ;$ Sigma). The mean ( \pm SD) length and weight of the $1+\mathrm{yr}$ fish were $21.9 \pm 2.3 \mathrm{~cm}$ (fork length) and $117.9 \pm 39.7 \mathrm{~g}$, respectively. The same parameters for the $0+\mathrm{yr}$ fish were $6.4 \pm 0.5 \mathrm{~cm}$ and $2.3 \pm 0.7 \mathrm{~g}$, respectively.

Adult male lingcod Ophiodon elongates were used as model predators in evasion trials. These fish were raised as part of the NWFSC's aquaculture operations at a separate field station (Manchester, WA) and were transported to the Mukilteo research facility. Lingcod were acclimated to seawater conditions at Mukilteo for $4 \mathrm{wk}$ before being used in predation trials. Fish were an average of $60.0 \pm 3.6 \mathrm{~cm}$ long and $1.78 \pm 0.28 \mathrm{~kg}$ in weight.

Neurophysiological recordings from the trout olfactory epithelium. Odorant-evoked electro-olfactograms (EOGs) were obtained using established procedures (Baldwin \& Scholz 2005). Briefly, fish were anaesthetized and immobilized, and the skin overlying the olfactory chamber was removed. Fish were placed in a plexiglass holder on a vibration isolation table. Stimulus-evoked EOGs were recorded from the sensory epithelium with a pair of glass microelectrodes using a custom LabVIEW program (Baldwin \& Scholz 2005). To evaluate the responsiveness of the trout olfactory system to carbaryl and a model odorant (L-serine, an amino acid), stock solutions of carbaryl (99\% purity; Chem Service) and L-serine (Sigma) were prepared in isopropanol (Sigma) and distilled water, respectively. Test solutions containing varying odorant concentrations were prepared by dilutions of these stocks in filtered seawater. During the recordings, the olfactory chamber was continually perfused with seawater. Odor-evoked EOGs were elicited with $10 \mathrm{~s}$ pulses of seawater alone (control), seawater containing isopropanol only $(0.01 \%$ carrier control), seawater containing carbaryl $\left(5,50\right.$ or $500 \mu \mathrm{g} \mathrm{l}^{-1}$ final concentration), or seawater containing L-serine $\left(10^{-6}, 10^{-5}\right.$ or $10^{-4} \mathrm{M}$ final concentration).

Behavioral avoidance. The avoidance of carbarylcontaminated seawater by cutthroat trout was evaluated using a 2 choice experimental chamber modified from Sprague (1968). The chamber consisted of a $1.8 \mathrm{~m}$ acrylic cylinder with a continuous flow of seawater $\left(4 \mathrm{l} \mathrm{min}^{-1}\right)$ entering at each end. Seawater exited the chamber via a ventral drain at the midline. A peristaltic 
pump was used to introduce solutions into either of the 2 seawater inputs located at the ends of the cylinder. Test solutions included seawater alone (negative control), $40 \mu \mathrm{g} \mathrm{l}^{-1}$ copper (copper chloride, Sigma; positive control) or $500 \mathrm{\mu g} \mathrm{l}^{-1}$ carbaryl as nominal concentrations (after dilution) in the treatment arm of the chamber. Individual fish were placed in the chamber and allowed to acclimate for $15 \mathrm{~min}$. A digital video camera (Canon ZR45) was then used to record the position of the fish for an additional $10 \mathrm{~min}$. During this $25 \mathrm{~min}$ total acclimation period the general level of motor behavior was monitored. Fish were pre-screened for activity and were excluded from behavioral trials if they did not cross the midline of the experimental chamber at least 6 times during the acclimation period. This resulted in $\mathrm{n}=24$ of 75 fish being tested, which is similar to the rate of acclimation originally described by Sprague (1968).

Behavioral avoidance trials were initiated by introducing a test solution (seawater, carbaryl, or copper) via one of the 2 inflows to the chamber. The arm used to introduce the test solution was alternated between successive trials. Based on preliminary dye tests, a 5 min diffusion period was sufficient to establish a uniform, well-mixed odorant distribution throughout one half of the chamber, with little crossover at the midline. Following this interval, the position of the fish relative to the midline was observed for $10 \mathrm{~min}$. Avoidance behavior was measured as the fraction of time that the fish spent in the arm containing the test solution (vs. the arm containing seawater alone) during the $10 \mathrm{~min}$ intervals pre- and post-odorant delivery.

Carbaryl exposure and chemical analyses. Carbaryl stock solutions (10 $\mathrm{mg} \mathrm{ml}^{-1}$ ) were prepared weekly in isopropanol. The final concentration of the isopropanol carrier in exposure tanks was $0.01 \%$. Carbaryl exposure was static and lasted either $2 \mathrm{~h}$ (predation study) or $6 \mathrm{~h}$ (all others). Treatment groups consisted of a seawater control, carrier (isopropanol) control, and carbaryl exposure ranging from $1 \mathrm{\mu g}^{-1}$ to $2000 \mu \mathrm{g} \mathrm{l}^{-1}$. Cutthroat trout were exposed to carbaryl in $0.6 \mathrm{~m}$ diameter (ca. 95 l) tanks with the exception of the experiment to measure the onset and recovery of carbaryl-induced AChE inhibition (see 'Results'), in which a $1.2 \mathrm{~m}$ diameter (ca. $700 \mathrm{l}$ ) tank was used.

For the carbaryl dose-response experiment, water samples were collected at the onset of the exposure $(t=0)$ and again at $6 \mathrm{~h}$ when the fish were removed from the test chambers. Tissue samples (dorsal axial muscle) were also collected from fish at the end of the $6 \mathrm{~h}$ exposure. Water and tissue samples were analyzed for carbaryl by an outside laboratory (Mississippi State Chemical Laboratory, Mississippi State, MS) using a Waters Carbamates system (equipped with a WISP model 712 auto-sampler and a Waters 470 scanning fluorescence detector) and standard procedures for high performance liquid chromatography (HPLC). The detection limits for carbaryl were $1 \mu \mathrm{g} \mathrm{l}^{-1}$ for water and $0.01 \mathrm{ppm}$ wet weight for tissue.

Carbaryl concentrations were only determined by HPLC for the dose-response experiment. Nominal exposures were used for subsequent experiments, and the degree of AChE inhibition in muscle was compared to the results of the dose-response experiment to ensure consistency of dosing across experiments.

Cholinesterase enzymatic activity. Brain and muscle tissues were dissected from the fish immediately following exposure, flash frozen in liquid nitrogen, and stored at $-80^{\circ} \mathrm{C}$. For AChE assays, tissues were thawed and homogenized in $50 \mathrm{mg} \mathrm{ml}^{-1}$ (brain) or $40 \mathrm{mg} \mathrm{ml}^{-1}$ (muscle) PBS-T (10 mM phosphate buffered saline containing $1 \%$ Triton X-100). Cholinesterase activity was determined using established procedures (Sandahl et al. 2005, Scholz et al. 2006). Homogenates were spun in an ultracentrifuge at $120000 \times g$ for $30 \mathrm{~min}$ at $4^{\circ} \mathrm{C}$, and the supernatant was removed and aliquoted. The conventional colorimetric assay of Ellman et al. (1961), as modified for a 96-well plate and for salmonids by Sandahl et al. (2005), was used to determine the rate of substrate hydrolysis. Enzyme activity was assayed on an Optimax plate reader (Molecular Devices) at $415 \mathrm{~nm}$. Substrate and tissue blanks were included and rates of activity were corrected for spontaneous hydrolysis and nonspecific reduction of the chromagen (Scholz et al. 2006). Values were normalized to the protein content of each sample and are expressed relative to AChE activity in the carrier (isopropanol) control exposure group. Final well concentrations of reagents and tissue were $2.6 \mathrm{mM}$ acetylthio-

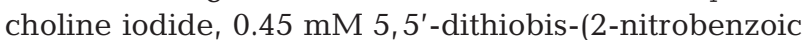
acid) (DTNB) and $1 \mathrm{mg} \mathrm{ml}^{-1}$ brain or muscle tissue. All chemicals were obtained from Sigma.

Swimming performance. Swimming performance was measured in one of 3 identical Blazka-type swimming chambers $(1.52 \mathrm{~m}$ long $\times 0.24 \mathrm{~m}$ outer diameter; Beamish 1978). Briefly, each chamber consisted of 2 acrylic cylinders, one smaller diameter cylinder nested inside the other. Fish were placed in the inner cylinder and constrained by a removable baffle at the front and a screen at the rear. Water was forced from the front to the rear of the inner cylinder and back to the front (along the outside of the inner cylinder) by a motordriven propeller at the rear of the chamber. The speed of the motor and an in-stream flow meter (Swoffer 3000, Swoffer Instruments) were used to calculate the recirculating flow rate in the inner cylinder.

Cutthroat trout were exposed to carbaryl at concentrations of 500,750 and $1000 \mu \mathrm{g} \mathrm{l}^{-1}$ for $6 \mathrm{~h}$. To monitor the corresponding effect of carbaryl on muscle AChE activity, additional fish $(\mathrm{n}=24)$ were exposed at these 
same concentrations and then sacrificed for tissue collection. Carbaryl-exposed fish were inserted into the chamber and allowed to acclimate for $20 \mathrm{~min}$ with the motor turned off $\left(0 \mathrm{~cm} \mathrm{~s}^{-1}\right.$ flow $)$. A slow inflow of fresh seawater into the top of the chamber served to maintain ambient water quality conditions (i.e. temperature and dissolved oxygen) in the swim chamber. Trials began by establishing a $45 \mathrm{~cm} \mathrm{~s}^{-1}$ flow for $10 \mathrm{~s}$. The fish were subsequently observed for $5 \mathrm{~min}$ and then scored as 'passing' if they were able to orient to the flow and were swimming against the current. In contrast, fish were scored as 'failing' if they were not oriented into the flow and were pressed against the screen at the rear of the inner cylinder (see Fig. 5).

Predator avoidance. Lingcod were not fed for $1 \mathrm{wk}$ prior to the experiment, after which they ate only what they captured during predation trials. The lingcod were maintained separately in 5 groups of 3, and 3 trials were conducted per day, so that each lingcod was used only once per week. The ability of cutthroat trout to avoid a model predator was assessed using the method of Olla et al. (1992). Evasion success was monitored in a $2.7 \mathrm{~m}$ diameter tank filled to a depth of $0.9 \mathrm{~m}$ with a continual flow of seawater. Prior to each predation trial, a single lingcod was placed into the experimental tank and allowed to acclimate for $2 \mathrm{~h}$. During this $2 \mathrm{~h}$ interval, a group of trout $(n=12)$ was placed in seawater alone and a second group $(\mathrm{n}=12)$ was exposed to isopropanol (carrier only) or 200, 500 or $1000 \mu \mathrm{g} \mathrm{l}^{-1}$ carbaryl (plus carrier). Adipose fins were clipped to differentiate animals exposed to seawater from those exposed to either carrier alone or carbaryl and carrier, and the fin-clipped group (seawater or exposed) was alternated between trials.

At the end of the $2 \mathrm{~h}$ exposure, 10 fish from each group were mixed together in a single small enclosure within the $2.7 \mathrm{~m}$ tank. Muscle samples were collected from the remaining pair of fish to determine AChE inhibition. After 15 min of acclimation, the predation trial was started by lifting the enclosure from the experimental tank and allowing the lingcod access to the trout. The test was stopped after either $1 \mathrm{~h}$ or after approximately half of the trout in the tank ( $\mathrm{n}=10$ ) were consumed, whichever came first. The remaining trout were collected, identified by fin clips, and recorded for length and weight. The relative rate of predation was determined by dividing the number of exposed (carrier or carbaryl) trout eaten by the total number of trout preyed upon by the lingcod, with a value of 0.5 representing no difference between groups.
Software and data analyses. Data and statistical analyses were performed using Microsoft Excel (Microsoft) and Kaleidagraph (Synergy Software). ImageJ (NIH, available online at http://rsb.info.nih. gov/ij/download.html) was used to analyze the video recordings of the avoidance behavior. Canvas (ACD Systems of America) and Kaleidagraph were used for production of graphics.

\section{RESULTS}

\section{Trout fail to detect carbaryl}

Lack of olfactory response. The electrical field potentials (olfactory responses) evoked from the sensory epithelium of cutthroat trout in response to seawater, isopropanol (carrier), carbaryl, and L-serine are shown in Fig. 2. As previously reported for other salmonid species (e.g. coho salmon; Baldwin et al. 2003), increasing concentrations of the conventional odorant L-serine $\left(10^{-6}, 10^{-5}, 10^{-4} \mathrm{M}\right)$ evoked EOGs with amplitudes that increased in a dose-dependent fashion. Conversely, the olfactory responses produced by the carrier (isopropanol) alone, or by 5, 50, or $500 \mu \mathrm{g} \mathrm{l}^{-1}$ carbaryl were not statistically significantly different from that produced by perfusing the olfactory chamber with seawater alone $(\mathrm{n}=20$ fish per group, $p>0.05$, 1-way ANOVA with a Dunnett post hoc test). Note that in terms of molar concentration, the highest carbaryl concentration $\left(500 \mathrm{\mu g} \mathrm{l}^{-1}\right.$ or $\left.10^{-5.6} \mathrm{M}\right)$ is within the range of L-serine concentrations that evoke EOGs.

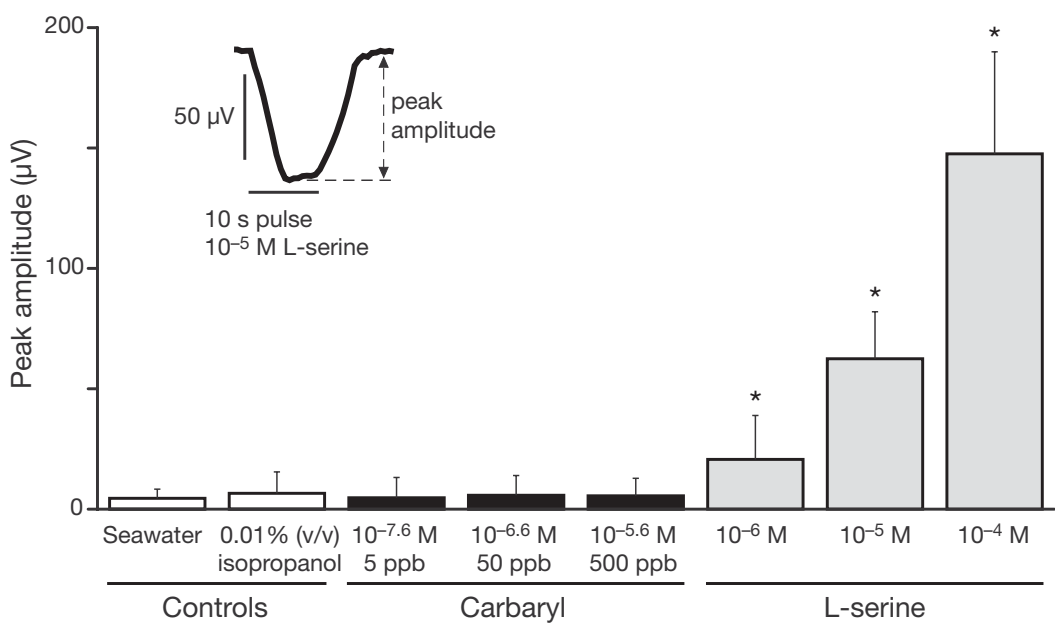

Fig. 2. Oncorhynchus clarki clarki. While 10 s pulses of 3 concentrations of L-serine (positive control) produced dose-dependent electro-olfactogram (EOG) responses, pulses of seawater, isopropanol (carrier control), and 3 concentrations of carbaryl did not produce significant odor-evoked EOG responses. Bars are mean $\pm \mathrm{SD}(\mathrm{n}=20 \mathrm{fish})$. The inset is an example of a typical EOG evoked by a $10 \mathrm{~s}$ pulse of $10^{-5} \mathrm{M} \mathrm{L-serine.} \mathrm{Asterisks} \mathrm{indicate} \mathrm{a} \mathrm{significant} \mathrm{difference} \mathrm{from} \mathrm{control}$ pulses of seawater alone ( $p<0.05,1$-way ANOVA with a Dunnett post hoc test) 
Lack of avoidance behavior. The extent to which trout avoided seawater alone $(\mathrm{n}=8)$, dissolved copper (40 $\mathrm{gg}^{-1}$ final concentration copper; $\mathrm{n}=9$ ), or dissolved carbaryl (500 $\mu \mathrm{g} \mathrm{l}^{-1}$ final concentration; $\mathrm{n}=$ 7) is shown in Fig. 3. Salmonids are known to avoid dissolved copper (e.g. Hansen et al. 1999), and copper was therefore included in the behavioral avoidance trials as a positive control. Fish from each of the 3 groups did not show a significant preference for, or avoidance of, the test arm of the chamber before the introduction of the test solution (black bars in Fig. 3). As expected, individual trout significantly avoided seawater containing dissolved copper $(\mathrm{p}<$ 0.05, paired $t$-test; white bar in Fig. 3). Animals did not significantly avoid seawater alone or seawater containing carbaryl $(\mathrm{p}>0.05$, paired $t$-tests; white bars in Fig. 3).

\section{Carbaryl levels in trout tissues reflect seawater concentrations}

Dissolved concentrations of carbaryl were measured in seawater at the beginning and end of the $6 \mathrm{~h}$ doseresponse experiment. Carbaryl levels were also analyzed in fish muscle tissue after the $6 \mathrm{~h}$ exposure. The carbaryl concentrations plotted in Fig. 4a are the measured concentrations (the mean of the initial and final concentrations) for each exposure group. No carbaryl was detected in seawater from the 2 control exposures (seawater or seawater containing isopropanol carrier alone). The concentration of carbaryl in trout muscle tissue was 1.7 -fold higher than the levels in corresponding seawater at the end of the $6 \mathrm{~h}$ exposure interval (linear-regression, slope $=1.7, \mathrm{r}^{2}=0.997, \mathrm{p}<$ 0.0001).

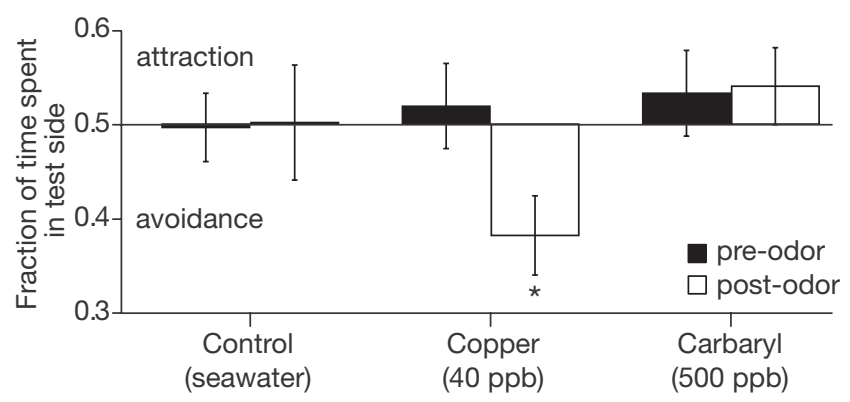

Fig. 3. Oncorhynchus clarki clarki. Behavioral avoidance tests show that trout do not avoid water containing carbaryl. Prior to the introduction of a test odor, fish showed no pre-odor preference to a particular side of the test chamber (black bars). Once the test odor was introduced, trout significantly avoided the test side if the odor was copper (positive control) ( $\mathrm{n}=9, \mathrm{p}<0.05$ in a paired $t$-test as indicated by the asterisk), but not if the odor was seawater $(n=8)$ or carbaryl $(n=7)$. Bars are mean $\pm \mathrm{SD}$

\section{Inhibition of AChE activity}

Dose dependency in brain and muscle tissue. AChE activity was reduced in the muscle (squares, Fig. 4a) and brains (circles, Fig. 4a) of cutthroat trout exposed to carbaryl for $6 \mathrm{~h}$. The dose-response curves for both tissues were similar (Fig. 4a), indicating a similar degree of enzyme inhibition by the insecticide. The $\mathrm{IC}_{50}$ (concentration producing $50 \%$ inhibition) for muscle and brain tissue was 185 and $213 \mu \mathrm{g} \mathrm{l^{-1 }}$, respectively, and the benchmark concentrations corresponding to $20 \% \mathrm{AChE}$ inhibition $\left(\mathrm{BMC}_{20}\right)$ were $23 \mathrm{\mu g} \mathrm{l}^{-1}$ for muscle and $32 \mu \mathrm{g} \mathrm{l}^{-1}$ for brain tissue. For both tissues, no statistically significant differences were seen in the AChE activity of fish exposed to seawater alone compared to those exposed to isopropanol carrier alone ( $t$-tests; $\mathrm{p}=0.46$ for brain and $\mathrm{p}=0.87$ for muscle).

Onset is rapid but reversible. To profile the onset of carbaryl-induced AChE inhibition, as well as the recovery of enzyme activity following a short-term exposure, cutthroat trout were exposed to carbaryl at a nominal concentration of $500 \mu \mathrm{g} \mathrm{l}^{-1}$ for $6 \mathrm{~h}$ and then allowed to recover for $4 \mathrm{~d}$ (see Fig. $4 \mathrm{~b}$ ). A total of 84 fish were exposed to carbaryl in a single tank. During the exposure period, fish were subsampled in groups of 7 at $t=0$ (time zero) and at intervals of $2 \mathrm{~h}(2,4$ and $6 \mathrm{~h}$ ). The remaining fish were then transferred to clean seawater. Additional groups of 7 fish were sampled every $2 \mathrm{~h}$ for the first $6 \mathrm{~h}$ of recovery $(t=8,10$ and $12 \mathrm{~h})$ and then over longer intervals for the next few days $(t=24$, $36,48,72$ and $96 \mathrm{~h}$ ). The onset of AChE inhibition in the brain was rapid and near-maximal within $2 \mathrm{~h}$ of exposure. Enzyme activity showed initial recovery when animals were restored to clean seawater, and then gradually recovered to pre-exposure levels after $42 \mathrm{~h}$ in clean seawater (Fig. $4 \mathrm{~b}$ ).

\section{Behavioral effects of carbaryl}

Impaired orientation. The ability of cutthroat trout to react and orient to a sudden change in flow was used to assess swimming performance (Fig. 5a). The swimming performance of fish exposed to a carbaryl concentration of $500 \mathrm{\mu g} \mathrm{l}^{-1}$ (nominal) was not significantly different from control groups (seawater alone and isopropanol carrier) (Fig. 5b). In contrast, fish exposed to higher concentrations (750 and $1000 \mu \mathrm{g} \mathrm{l}^{-1}$ ) were statistically significantly impaired (Fisher's exact test, $\mathrm{p}<0.05, \mathrm{n}=15$ ) (Fig. 5b). The nominal carbaryl exposure in this experiment resulted in decreases in muscle AChE activity (percent relative to control; parentheses in Fig. $5 \mathrm{~b} ; \mathrm{n}=5$ per treatment) that were similar to the degree of inhibition observed in the dose-response experiment (see Fig. 4a). 

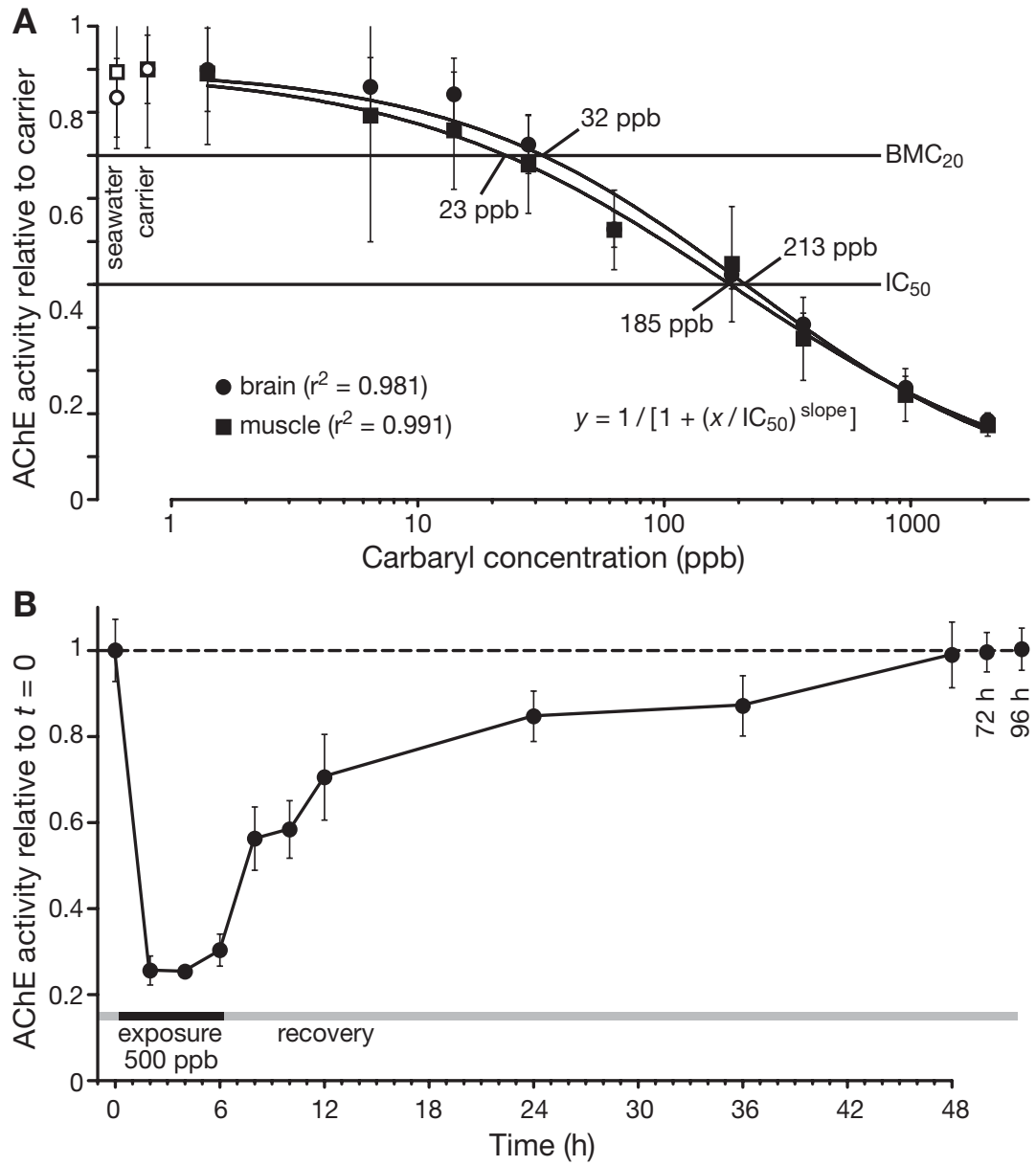

Fig. 4. Oncorhynchus clarki clarki. Dose-response curve and time-course for acetylcholinesterase inhibition produced by carbaryl exposure. (A) Exposure to carbaryl ( $6 \mathrm{~h}$ ) produced similar dose-response curves for both brain (circles) and muscle (squares) tissue acetylcholinesterase inhibition. Each value represents the mean $\pm \mathrm{SD}\left(\mathrm{n}=15\right.$ fish). The $50 \%$ inhibition concentrations $\left(\mathrm{IC}_{50}\right)$ for muscle and brain tissue were 185 and $213 \mu \mathrm{g} \mathrm{l}^{-1}(\mathrm{ppb})$, respectively. The benchmark concentrations for $20 \%$ acetylcholinesterase inhibition $\left(\mathrm{BMC}_{20}\right)$ were $23 \mu \mathrm{g} \mathrm{l}^{-1}$ for muscle and $32 \mu \mathrm{g} \mathrm{l}^{-1}$ for brain tissue. No significant acetylcholinesterase inhibition was observed in fish from the carrier control group. (B) The time-course for brain tissue acetylcholinesterase activity showed that maximum inhibition by $500 \mu \mathrm{g} \mathrm{l}^{-1}$ carbaryl occurred within $2 \mathrm{~h}$ of exposure and that recovery to pre-exposure levels required up to $42 \mathrm{~h}$. Values shown are the mean $\pm \mathrm{SD}(\mathrm{n}=7$ fish $)$

Disproportionate predation mortality. A brief $(2 \mathrm{~h})$ exposure to carbaryl resulted in a dose-dependent decrease in the ability of trout to avoid being consumed by lingcod (Fig. 6a). An increase in predation vulnerability was evident for fish exposed to $200 \mathrm{~g} \mathrm{l}^{-1}$, although this effect was not significant relative to controls. At higher carbaryl concentrations (500 and $1000 \mu \mathrm{g} \mathrm{l}^{-1}$ ), exposed fish were eaten at a significantly higher rate than trout treated with isopropanol carrier alone $(\mathrm{n}=6$ trials, 1 -way ANOVA with a Dunnett post hoc test). For all exposures, the corresponding degree of muscle $\mathrm{AChE}$ inhibition is shown (percent relative to control; parentheses in Fig. $6 \mathrm{a}, \mathrm{n}=7$ to 10 fish) and was similar to the observations from the dose-response experiment (see Fig. 4a). The relationship between muscle AChE activity and predation vulnerability is shown in Fig. 6b. Differential predation was evident as AChE inhibition (relative to unexposed fish) reached ca. $50 \%$ or more.

\section{DISCUSSION}

In this investigation we explored the question of whether estuarine applications of carbaryl might increase the predation-induced mortality of seawaterphase coastal cutthroat trout. We found that trout are unable to detect or avoid seawater contaminated with carbaryl. Moreover, short-term exposures to carbaryl $(<2 \mathrm{~h})$ at concentrations that have previously been detected in the Willapa Bay water column are sufficient to depress cholinesterase activity in trout brain and muscle tissue. These changes in brain chemistry correspond to impaired swimming performance, and carbaryl-exposed animals were consumed with greater frequency than unexposed fish by a marine predator. Therefore, cutthroat trout that forage in proximity to carbaryl-treated oyster beds are likely to suffer neurobehavioral impairments that lead to higher rates of predation mortality. Given a rapid dispersal of carbaryl in the estuary by turbulent forces (i.e. tides and wind), exposed trout that survive encounters with predators should recover in 1 to $2 \mathrm{~d}$ following a spray event.

Fish are known to reduce their exposure to certain environmental contaminants by actively avoiding polluted habitats. The avoidance of dissolved copper is a wellstudied example. Salmonids have previously been shown to avoid copper in laboratory assays (Hansen et al. 1999) and corresponding field studies (Goldstein et al. 1999). As expected from these earlier studies, cutthroat trout avoided dissolved copper $\left(40 \mathrm{\mu g} \mathrm{l}^{-1}\right)$ in seawater. In contrast, our neurophysiological recordings indicate that carbaryl does not appear to be an effective olfactory stimulus for cutthroat trout. The failure of cutthroat trout to detect carbaryl is consistent with previous reports of olfactory insensitivity to the carbamate insecticide carbofuran in coho salmon (Jarrard et 

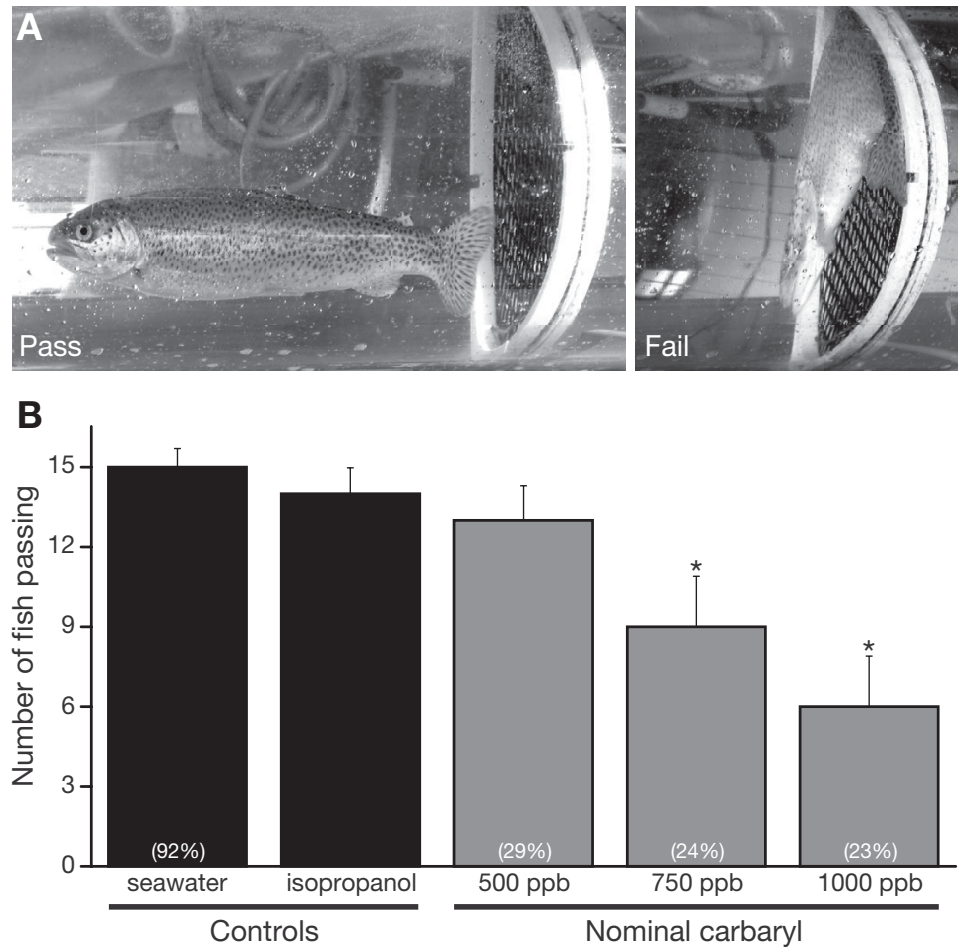

Fig. 5. Oncorhynchus clarki clarki. Exposure to carbaryl impairs the swimming performance of cutthroat trout. (A) Two fish are shown 5 min after starting the flow within the swim chamber. The fish on the left (pass) has oriented to the flow and is swimming clear of the rear screen. The fish on the right (fail) has failed to orient to the flow and is impinged on the rear screen. (B) The number of fish ( $\mathrm{n}=15$ total) able to orient and swim was significantly reduced after a $6 \mathrm{~h}$ exposure to nominal carbaryl concentrations of 750 and $1000 \mu \mathrm{g} \mathrm{l}^{-1}$. Fish exposed to $500 \mathrm{\mu g} \mathrm{l}^{-1}$ carbaryl and isopropanol (carrier control) did not perform significantly differently from seawater controls. Error bars represent 1 SD of the corresponding binomial distribution. Asterisks indicate a statistically significant difference from isopropanol carrier controls ( $p<0.05$, Fisher's exact test). The mean muscle acetylcholinesterase activity for each group of fish (relative to the carrier controls, $n=5$ ) is shown in parentheses

al. 2004) and Atlantic salmon (Waring \& Moore 1997). Moreover, trout did not avoid carbaryl at concentrations approximating the upper range of water column detections in Willapa Bay. Cutthroat trout are therefore unlikely to detect or avoid carbaryl as it is mobilized from oyster beds into the estuarine water column.

The uptake of carbaryl from the surrounding seawater was relatively consistent across a wide range of exposure concentrations, with a ratio of ca. 1.7 to 1 (axial muscle to seawater). This is consistent with the low $\mathrm{K}_{\mathrm{ow}}$ (octanol-water partition coefficient) of carbaryl and correspondingly low potential for bioaccumulation (International Programme on Chemical Safety, Environmental Health Criteria 153, available at www. inchem.org/documents/ehc/ehc/ehc153.htm). Accordingly, carbaryl should not pose a significant bioconcentration risk for trout or piscivorous predators higher in the estuarine food chain.
Carbaryl produced a near-maximal inhibition of AChE enzymatic activity in the trout central nervous system in less than $2 \mathrm{~h}$, which is well within the likely window for carbaryl exposure near treated tidelands in the estuary. This indicates that carbaryl is rapidly taken up and transported to cholinesterase targets in the trout nervous system and musculature. The dose-response curves for brain and muscle AChE inhibition were very similar, and no mortality was observed at exposure concentrations causing as much as $75 \%$ inhibition of brain enzyme activity $\left(1000 \mathrm{\mu g} \mathrm{l}^{-1}\right.$ or higher). This is consistent with previous reports of mortality occurring in fish only at relatively high levels of $\mathrm{AChE}$ inhibition (i.e. approximately 70 to $90 \%$, depending on the species; reviewed by Fulton \& Key 2001). When trout were restored to clean seawater, AChE activity recovered quickly over the first $6 \mathrm{~h}$ and then more gradually until reaching pre-exposure levels after $42 \mathrm{~h}$. Therefore, a transient exposure to carbaryl is likely to cause sublethal neurobehavioral effects in trout that persist for $2 \mathrm{~d}$ or less. This relatively rapid time course for recovery is consistent with the reversible association between carbaryl and the AChE enzyme (Aldridge \& Reiner 1972).

The relationship between AChE enzyme inhibition and behavioral impairment in salmonids and other fish has been a focus of several investigations over the past few decades (Fulton \& Key 2001). For example, Sandahl et al. (2005) recently showed that decreases in spontaneous swimming and feeding were closely correlated with brain $\mathrm{AChE}$ inhibition in juvenile coho salmon. Notably, both behaviors were significantly reduced in association with modest $(<10 \%)$ AChE inhibition. In contrast to these nuanced motor behaviors, measures of swimming stamina in fish have generally shown that animals with high rates of AChE inhibition can still manage to orient to flow and swim against a current. This suggests that swimming stamina in fish is affected only at high levels of brain AChE inhibition (reviewed by Fulton \& Key 2001). Stamina also appears to be a relatively insensitive endpoint in other vertebrates exposed to carbaryl, including snakes (Hopkins \& Winne 2006). Consistent with these previous findings, we did not observe significant behavioral impairment (i.e. reduction in swimming stamina) in fish with a high degree of $\mathrm{AChE}$ inhibition (i.e. up to ca. $70 \%$ ) relative to controls. However, we did not monitor fine motor behaviors such as prey capture (e.g. Sandahl et al. 


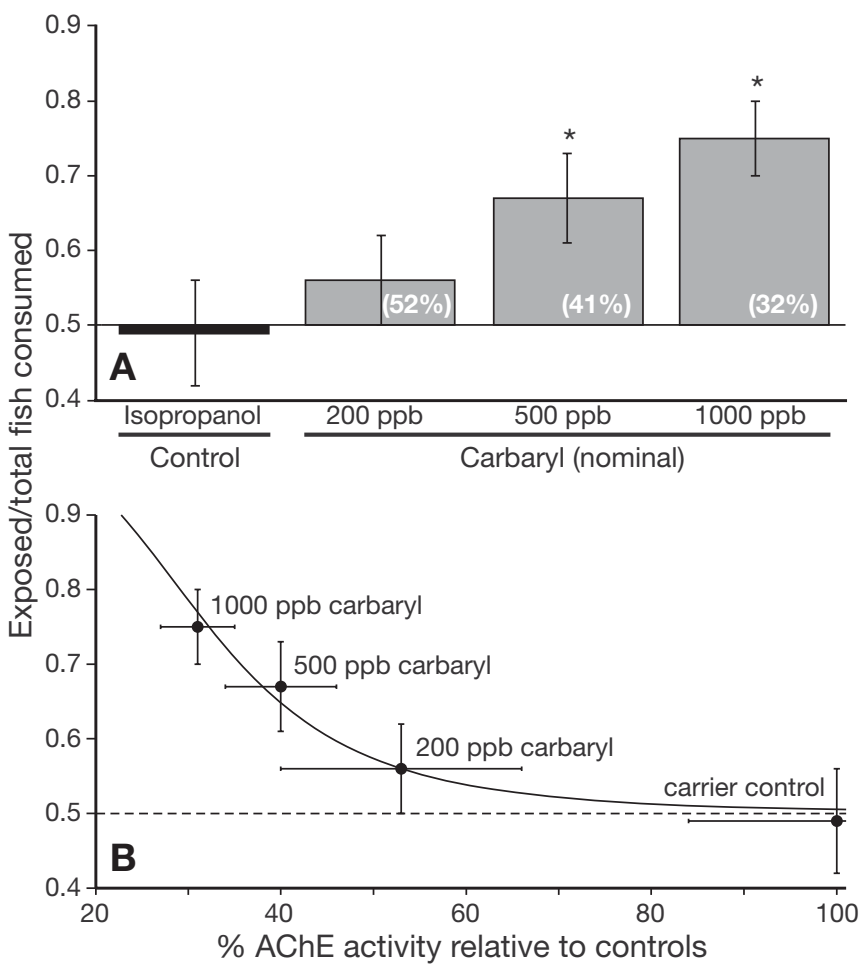

Fig. 6. Oncorhynchus clarki clarki. Carbaryl exposure produced dose-dependent increases in predation and decreases in acetylcholinesterase activity in cutthroat trout. (A) Exposure to carbaryl $(2 \mathrm{~h}$ ) produced a dose-dependent increase in predation. Bars represent the proportion of treated fish consumed relative to the total number consumed (means $\pm \mathrm{SD}$, $\mathrm{n}=6$ trials). A value of $0.5(50 \%)$ on the $y$-axis indicates equal lingcod predation on both dosed and control fish. Asterisks indicate a statistically significant difference from controls $(\mathrm{p}<$ 0.05, 1-way ANOVA with a Dunnett post hoc test). The mean muscle acetylcholinesterase (AChE) activity (relative to the carrier controls) for each exposure group ( $\mathrm{n}=7$ to 10 fish) is shown in parentheses. (B) A comparison of AChE activity with predation from each exposure group shows a trend of increasing predation vulnerability with decreasing AChE activity. Data shows the mean \pm SD. For qualitative purposes a sigmoid regression is shown (solid line)

2005). Low-dose exposures to carbaryl may therefore disrupt more subtle behaviors in cutthroat trout, but this remains to be determined.

Chemical contaminants in coastal environments can render exposed fish more susceptible to starvation, predation, disease, and other environmental stressors (Peterson et al. 2003). In terms of understanding the impacts of pollution on marine fish, predation assays have the advantage of providing an integrative measure of physiology and behavior (Kruzynski \& Birtwell 1994, Weis et al. 2001). In the present study, this included predator detection and avoidance as well as the ability of trout to evade an actual strike. Predation assays also convey information about the possibility of mortality following short-term, ecologically relevant carbaryl exposures. This is a key consideration for the conservation of at-risk species, in part because individual survival data have implications at higher biological scales (i.e. wild populations) where conservation decisions are usually made. Moreover, consumption by harbor seals, spiny dogfish, adult salmon, and other predators are thought to be the major cause of marine mortality for sea-run cutthroat trout (reviewed by Trotter 1989). Our predation trials were designed to evaluate the impacts of real-world carbaryl exposures on the ability of trout to avoid a predator. Under natural exposure conditions, however, the risk of ecological death is very likely to depend on whether the predator is a piscivorous bird, a marine mammal, or a marine fish (and, if the latter, whether the predatory fish is also exposed to carbaryl). These kinds of interspecies interactions are important determinants of cutthroat trout survival, albeit very difficult to capture or otherwise address in experimental field studies.

It is important to note that this study did not address the potential indirect effects of carbaryl on coastal cutthroat trout. 'Indirect' refers to the possibility of cascading ecological effects, mediated in the present context by the impacts of carbaryl on the estuarine food chain (e.g. a reduction in the trout prey species). The indirect effects of contaminants are thought to be common in the marine environment, and they may be as (or more) significant than direct, sublethal effects on fish (reviewed by Fleeger et al. 2003). Carbaryl is by design highly toxic to burrowing shrimp and other estuarine crustaceans. Moreover, fish kills involving staghorn sculpin, saddleback gunnels, English sole, sand sole, shiner perch Cymatogaster aggregata, starry flounder Platichthys stellatus, bay gobies, and three-spine sticklebacks have been documented following carbaryl spraying (reviewed by Feldman et al. 2000, see also Dumbauld et al. 2001). Crustaceans and small fish are important components of the cutthroat trout diet as they forage in the estuary during the summer months (Trotter 1989), and trout are known to prey specifically on burrowing shrimp (Posey 1986). It has been previously estimated that carbaryl application to the tidelands in Willapa Bay as well as neighboring Grays Harbor results in the annual removal of 66 million shrimp (or 476 tons of biomass; reviewed in Feldman et al. 2000), although carbaryl is currently applied to less than $6 \%$ of the total intertidal area in Willapa Bay (Dumbauld et al. 2001). Nevertheless, by diminishing the abundance of various prey species for several weeks after oyster beds are treated in the summer, carbaryl has the potential to indirectly reduce the growth of seawater-phase cutthroat trout. However, the significance of such indirect effects, if any, has yet to be explored. 
Finally, although this study was focused on a very specific pesticide use in the estuarine environment, our findings are likely to have broader geographical implications. Dozens of currently used organophosphate and carbamate insecticides target cholinesterase enzymes in fish. These anticholinesterase agents are widely detected in the surface waters of many countries throughout the world (e.g. USGS 1999). Several chemicals such as chlorpyrifos and carbofuran are considerably more potent than carbaryl in terms of their inhibition of fish AChE (Scholz et al. 2006). These insecticides are known to block brain enzyme activity at comparatively low concentrations that are more typical of exposure to urban and agricultural runoff in coastal habitats (Sandahl et al. 2005). Cholinesterase inhibition has previously been used as a bioindicator of chemical pollution in the marine environment (e.g. Galgani et al. 1992). However, the consequence of this biochemical response at higher biological scales has not been widely investigated. Here we have shown that AChE inhibition corresponds to an increase in mortality due to predation, presumably via sublethal effects on the behavioral performance of the exposed fish. This relationship between sublethal AChE inhibition and fish survival may extend to most or all of the pesticides that share the anticholinesterase mode of action. If so, our results should provide greater context for resource managers and others who must assess the ecological impacts of a large and important class of environmental contaminants.

Acknowledgements. This work was supported by grant \#200210007.1 from the US Fish and Wildlife Service's Division of Environmental Quality, National Contaminants Program to N.L.S. and J.W.D. We are grateful to the staff of the Eells Spring hatchery for providing animals, F. Sommers for animal care, C. Stehr, T. Linbo and C. Laetz for laboratory assistance, and B. Feist and J. Colman for comments on the manuscript.

\section{LITERATURE CITED}

Aldridge WN, Reiner E (1972) Enzyme inhibitors as substrates: interactions of esterases with esters of organophosphorus and carbamic acids, Vol 26. North-Holland Publishing, Amsterdam

Armstrong DA, Millemann RE (1974) Effects of the insecticide carbaryl on clams and some other intertidal mud flat animals. J Fish Res Board Can 31:466-470

Baldwin DH, Scholz NL (2005) The electro-olfactogram: an in vivo measure of peripheral olfactory function and sublethal neurotoxicity in fish. In: Ostrander GK (ed) Techniques in aquatic toxicology, Vol 2. CRC Press, Boca Raton, FL, p 257-276

Baldwin DH, Sandahl JF, Labenia JS, Scholz NL (2003) Sublethal effects of copper on coho salmon: impacts on nonoverlapping receptor pathways in the peripheral olfactory nervous system. Environ Toxicol Chem 22: 2266-2274

Beamish FWH (1978) Swimming capacity. In: Hoar WS,
Randall DJ (eds) Fish physiology, Vol 7. Academic Press, New York, 101-187

Carlson RW, Bradbury SP, Drummond RA, Hammermeister DE (1998) Neurological effects of startle response and escape from predation by medaka exposed to organic chemicals. Aquat Toxicol 43:51-68

Dumbauld BR, Brooks KM, Posey MH (2001) Response of an estuarine benthic community to application of the pesticide carbaryl and cultivation of Pacific Oysters (Crassostrea gigas) in Willapa Bay, Washington. Mar Pollut Bull 42:826-844

Ellman GL, Courtney KD, Valentino AJ, Featherstone RM (1961) A new and rapid colorimetric determination of acetylcholinesterase activity. Biochem Pharmacol 7:88-95

Feldman KL, Armstrong DA, Dumbauld BR, DeWitt TH, Doty DC (2000) Oysters, crabs, and burrowing shrimp: review of an environmental conflict over aquatic resources and pesticide use in Washington State's (USA) coastal estuaries. Estuaries 23:141-176

Fleeger JW, Carman KR, Nisbet RM (2003) Indirect effects of contaminants in aquatic ecosystems. Sci Total Environ 317:207-233

Fulton MH, Key PB (2001) Acetylcholinesterase inhibition in estuarine fish and invertebrates as an indicator of organophosphorus insecticide exposure and effects. Environ Toxicol Chem 20:37-45

Galgani F, Bocquené G, Cadiou Y (1992) Evidence of variation in cholinesterase activity in fish along a pollution gradient in the North Sea. Mar Ecol Prog Ser 91:77-82

Goldstein JN, Woodward DF, Farag AM (1999) Movements of adult Chinook salmon during spawning migration in a metals-contaminated system, Coeur d'Alene River, Idaho. Trans Am Fish Soc 128:121-129

Hansen JA, Marr JCA, Lipton J, Cacela D, Bergman HL (1999) Differences in neurobehavioral responses of chinook salmon (Oncorhynchus tshawytscha) and rainbow trout (Oncorhynchus mykiss) exposed to copper and cobalt: Behavioral avoidance. Environ Toxicol Chem 18:1972-1978

Hopkins WA, Winne CT (2006) Influence of body size on swimming performance of four species of neonatal natricine snakes acutely exposed to a cholinesterase-inhibiting pesticide. Environ Toxicol Chem 25:1208-1213

Jarrard HE, Delaney KR, Kennedy CJ (2004) Impacts of carbamate pesticides on olfactory neurophysiology and cholinesterase activity in coho salmon (Oncorhynchus kisutch). Aquat Toxicol 69:133-148

Johnson OW, Ruckelshaus MH, Grant WS, Waknitz FW, Garrett AM, Bryant GJ, Neely K, Hard JJ (1999) Status review of coastal cutthroat trout from Washington, Oregon, and California. US Dept. of Commerce, NOAA Tech. Memo. NMFS-NWFSC-37

Kruzynski GM, Birtwell IK (1994) A predation bioassay to quantify the ecological significance of sublethal responses of juvenile Chinook salmon (Oncorhynchus tshawytscha) to the antisapstain fungicide TCMTB. Can J Fish Aquat Sci 51:1780-1790

Little EE, Archeski RD, Flerov BA, Kozlovskaya VI (1990) Behavioral indicators of sublethal toxicity in rainbow trout. Arch Environ Contam Toxicol 19:380-385

Olla BL, Davis MW, Schreck CB (1992) Comparison of predator avoidance capabilities with corticosteroid levels induced by stress in juvenile Coho salmon. Trans Am Fish Soc 121:544-547

Peterson CH, Rice SD, Short JW, Esler D, Bodkin JL, Ballachey BE, Irons DB (2003) Long-term ecosystem response to the Exxon Valdez oil spill. Science 302:2082-2086

Posey MH (1986) Predation on a burrowing shrimp: distribu- 
tion and community consequences. J Exp Mar Biol Ecol 103:143-161

Quinn TP, Myers KW (2004) Anadromy and the marine migrations of Pacific salmon and trout: Rounsefell revisited. Rev Fish Biol Fish 14:421-442

Sandahl JF, Baldwin DH, Jenkins JJ, Scholz NL (2005) Comparative thresholds for acetylcholinesterase inhibition and behavioral impairment in coho salmon exposed to chlorpyrifos. Environ Toxicol Chem 24:136-145

Scholz NL, Truelove NK, Labenia JS, Baldwin DH, Collier TK (2006) Dose-additive inhibition of chinook salmon acetylcholinesterase activity by mixtures of organophosphate and carbamate insecticides. Environ Toxicol Chem 25: $1200-1207$

Simenstad CA, Fresh KL, Salo EO (1982) The role of Puget Sound and Washington coastal estuaries in the life history of Pacific salmon: an unappreciated function. In: Kennedy VS (ed) Estuarine comparisons. Academic Press, New York, NY, p 343-364

Sprague JB (1968) Avoidance of copper-zinc solutions by young salmon in the laboratory. J Water Pollut Control Fed 36:990-1004

Editorial responsibility: Otto Kinne (Editor-in-Chief), Oldendorf/Luhe, Germany
Taylor P, Brown JH (1999) Acetylcholine. In: Siegel GJ, Agranoff BW, Albers RW, Fisher SK, Uhler MD (eds) Basic neurochemistry: molecular, cellular, and medical aspects. Lippincott-Raven Publishers, Philadelphia, PA, p 213-242

Trotter PC (1989) Coastal cutthroat trout: a life history compendium. Trans Am Fish Soc 118:463-473

USGS (United States Geological Survey) (1999) The quality of our nation's waters - nutrients and pesticides. USGS Circular 1225

Waring CP, Moore A (1997) Sublethal effects of a carbamate pesticide on pheromonal mediated endocrine function in mature male Atlantic salmon (Salmo salar L.) parr. Fish Physiol Biochem 17:203-211

WDOE (Washington Department of Ecology) (1999) Screening survey of carbaryl $\left(\operatorname{Sevin}^{\mathrm{TM}}\right)$ and 1-naphthol concentrations in Willapa Bay sediments. Washington Department of Ecology Publication No. 99-323

Weis JS, Smith G, Zhou T, Santiago-Bass C, Weis P (2001) Effects of contaminants on behavior: Biochemical mechanisms and ecological consequences. BioScience 51: $209-217$

Submitted: September 18, 2006; Accepted: December 19, 2006 Proofs received from author(s): January 5, 2007 